\title{
The genus Manfreda (Asparagaceae; Agavoideae) in Guerrero, Mexico: RICHNESS, DISTRIBUTION AND THE DESCRIPTION OF A NEW SPECIES \\ El género Manfreda (Asparagaceae; Agavoideae) en Guerrero, México: RIQUEZA, DISTRIBUCIÓN Y LA DESCRIPCIÓN DE UNA ESPECIE NUEVA
}

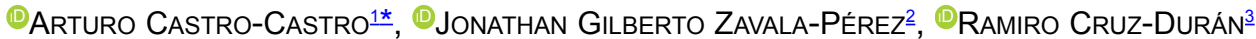

\begin{abstract}
${ }^{1}$ Cátedras CONACYT - Instituto Politécnico Nacional, Centro Interdisciplinario de Investigación para el Desarrollo Integral Regional, Unidad Durango (CIIDIR-Durango), Victoria de Durango, Durango, México.

2Universidad Veracruzana, Facultad de Ciencias Biológicas y Agropecuarias, Tuxpan, Veracruz, México. ${ }^{3}$ Universidad Nacional Autónoma de México, Facultad de Ciencias, Departamento de Biología Comparada, Coyoacán, Ciudad de México, México.
\end{abstract}

*Author for correspondence: arca68@hotmail.com

\begin{abstract}
Background: Manfreda includes 37 species distributed from southeastern United States to Honduras. The Pacific Lowlands and Sierra Madre del Sur biogeographic provinces and Guerrero state are the centers of species richness and endemism for the genus in Mexico.

Questions: How is the geographical distribution of Manfreda in Guerrero? Some specimen does not match any known Manfreda species, could be these collections a new species?

Studied species: Fourteen Manfreda species.

Study site: Guerrero, Mexico.

Methods: The analysis was based on specimens reviewed from 19 herbaria, fieldwork, and records in specialized literature. The richness was quantified by municipalities, biogeographic provinces, and a grid cell, using geographic information systems. The morphological descriptions and the recognition of new species are based on traditional taxonomic methods.

Results: Database included 86 records for 14 species. The richness is concentrated in 10 cells located in the transition between the Balsas Basin, Transmexican Volcanic Belt and the Sierra Madre del Sur. Some specimens that could not be assigned to any of the known species in Manfreda and proposed as a new species, which is presented with illustrations, an identification key, and a distribution map.

Conclusions: Given the richness, the endemism, and the low density of collections of Manfreda in Guerrero, we found that the richness is likely greater than previously estimated and it could be expected to find new species. It is advisable to focus on the collection towards the Pacific Lowlands, since there is the greatest richness in Mexico.
\end{abstract}

Keywords: Agavaceae tribe Poliantheae, amole, Balsas Basin, Sierra Madre del Sur, Transmexican Volcanic Belt.

\section{Resumen}

Antecedentes: Manfreda incluye 37 especies distribuidas desde el sureste de Estados Unidos hasta Honduras. Las provincias biogeográficas Tierras Bajas del Pacífico y Sierra Madre del Sur, y el estado de Guerrero son centros de riqueza y endemismo para Manfreda en México.

Preguntas: ¿Cómo es la distribución geográfica de Manfreda en Guerrero? Algunos especímenes no coinciden con ninguna especie conocida de Manfreda, ¿podrían ser estas colectas una especie nueva?

Especies de estudio: Catorce especies de Manfreda.

Sitio de estudio: Guerrero, México.

Métodos: El análisis se basó en la revisión de especímenes en 19 herbarios, trabajo de campo y registros en literatura especializada. La riqueza se cuantificó por municipios, provincias biogeográficas y una cuadrícula, utilizando sistemas de información geográfica. Las descripciones morfológicas y el reconocimiento de la especie nueva se basaron en métodos taxonómicos tradicionales.

Resultados: La base de datos incluyó 86 registros para 14 especies. La riqueza se concentra en 10 celdas en la transición entre la Cuenca del Balsas, Faja Volcánica Transmexicana y Sierra Madre del Sur. Algunos especímenes que no pudieron asignarse a ningún taxon conocido de Manfreda, se proponen como una especie nueva, acompañada de ilustraciones, una clave de identificación y un mapa de distribución.

Conclusiones: Dada la diversidad, el endemismo y la baja cobertura de las colecciones de Manfreda en Guerrero, esperamos que la riqueza sea mayor a la registrada y que exploraciones futuras revelen la existencia de especies nuevas. Es aconsejable dirigir recolecciones a las Tierras Bajas del Pacífico, donde existe la mayor riqueza en México.

Palabras clave: Agavaceae tribu Poliantheae, amole, Cuenca del Balsas, Faja Volcánica Transmexicana, Sierra Madre del Sur. 
The genus Manfreda Salisb. (Asparagaceae; Agavoideae) comprises polycarpic perennial herbs, with an upright bulb and a globose to cylindrical corm with fleshy and contractile roots. The plants produce thin to succulent leaves, organized in a basal rosette. The inflorescences are more frequently spiciform with solitary and sessile flowers at the nodes, but it can also be racemose with paired and pedicellate flowers, in both cases the flowers are subtended by one bract and one or two bracteoles (Castro-Castro et al. 2018). Manfreda includes 37 species distributed from the southeastern United States, throughout Mexico, and in Central America north of Honduras and El Salvador (Verhoek-Williams 1975, Castro-Castro et al. 2017, 2018). All species, except M. fusca Ravenna, occur in Mexico, whereas Guerrero and Jalisco are the most species rich states, with 14 and 12 species respectively (Castro-Castro et al. 2017, 2018).

Manfreda inhabit moist to xeric habitats with cold to mild winters. Commonly, the plants grow in open sunny or partial to deep shade sites in pine-oak forest, grassland, and tropical dry forest from sea level to $3,250 \mathrm{~m}$ (Castro-Castro et al. 2017, 2018). Although the range of distribution and ecological preferences of Manfreda are wide, there is a concentration of species towards the Pacific Lowlands biogeographic province in Mexico, where 16 species are found.

Throughout their area of distribution, Manfreda species are colloquially known as akasman, American aloe, American amole, amole, amole cenizo, amole de rio, amole pa' chango, amoli, amolilla, apintli, aporaka, azucena sabanera, biaa'toba, calpaich, cebolla de cerro, chupac, c ‘ipal, huaco, coyamole, jabón de hormiga, lechuguilla de castilla, lengua de lagartija, mezcalito, nama choco, oreja de liebre, soap plant, sotol, spice lily, taiicholi, Virginian agave, or wild tuberose (Verhoek 1978, Castillejos-Cruz 2009). In some regions of Mexico, their bulbs, corms, and fleshy roots are macerated, dissolved in water, and used as a soap substitute to wash clothes and hair, as poison for artisanal fishing, and as a remedy against snake bite, stomach colic and headache (Verhoek 1978). In addition, the plants have a high ornamental potential (Rodríguez \& Castro-Castro 2007), and the scape of inflorescences have been employed to make arrows for hunting (Verhoek 1978).

Given the existence of the high diversity of Manfreda between the political and natural boundaries in Guerrero, in this document we decided to present an analysis of the richness and geographical distribution of the genus in the state. Furthermore, during the revision of herbaria and data collection for the biogeographic analyses, we noted some specimens from the north of Guerrero in the Balsas Basin biogeographic province that did not match with any known species of Manfreda due to the size of different vegetative structures of individuals, the quantity of flowers in the inflorescence, and the perigone shape. Hence, after an analysis of herbarium vouchers and live plants from a recent field collection, review of relevant literature, comparisons with the most related taxa in the genus, and critical comments from experts, we recognize this as a new species. The biogeographic analysis and the description of the new species are accompanied with a map, illustrations, and a key to Manfreda of Guerrero.

\section{Materials and methods}

Geographical data and richness analyses. Data were obtained from herbarium specimens in the following collections: CHAPA, CIIDIR, ENCB, FCME, FEZA, IBUG, IEB, and MEXU (acronyms according to Thiers 2019). We also examined the virtual herbaria of ARIZ, ASU, BH, F, GH, MICH, MO, NY, RSABG, US, and WIS; and searched for specimens in the Southwest Environmental Information Network (SEINet) from Symbiota content management system (Gries et al. 2014). In addition, taxonomic treatments, monographs, and floristic studies were reviewed for distributional data (Matuda 1975, Verhoek-Williams 1975, Piña 1985 a, b, c, Piña 1986, McVaugh 1989, Ayala-Hernández 2006, Rodríguez \& Castro-Castro 2007, Castillejos-Cruz 2009, Rodríguez 2009, García-Mendoza 2011, Castro-Castro et al. 2017, 2018). When doubtful taxonomic identity records were detected, digitalized voucher specimens were analyzed, or images were requested from the staff of the corresponding herbaria.

Occurrence data was cleaned by eliminating repeated records and ambiguous locations and then visualized using the program ArcView GIS ver. 10.3 (ESRI 2014). The number of Manfreda species in Guerrero was quantified by municipality, vegetation type (Rzedowski 1990), biogeographic province (Morrone et al. 2017), and a standardized grid cell. The grid cell size was chosen according to the criteria of Willis et al. (2003), with the modification of Suárez-Mota \& Villaseñor (2011). Based on this method, the maximum distance of each taxon was averaged, and the value was divided by the number of species with maximum distance values greater than zero, for which 13 species reached the value in our analysis. The quotient was used to define the length of the cell. The grid analysis was performed with DIVA-GIS 4.2 (Hijmans et al. 2004). In this way, the state of Guerrero was divided into 162 cells of $144 \mathrm{~km}^{2}$.

Taxonomic treatment. The morphological description and illustration of the new species are based on traditional taxonomic methods (Simpson 2006). Descriptions and measurements were carried out under a Zeiss Stemi 
305 stereomicroscope. The line illustration of the new species was prepared from herbarium specimens, alcoholpreserved material and digital photos. The terminology used follows Verhoek-Williams (1975), Castillejos-Cruz (2009), and Castro-Castro et al. (2017, 2018). The morphological data obtained from the revised herbaria specimens were summarized to produce the descriptions, which served to prepare the identification key and the diagnosis of the new species. The conservation status of the new species was determined based on field observations and applying the IUCN red list criteria (IUCN 2019). We used GeoCAT program (Bachman et al. 2011) to estimate the extent of occurrence (EOO) and area of occupancy (AOO) indices for evaluating the geographic range.

\section{Results}

Geographical data and richness analyses. Our database included 86 different records, with 114 specimens, for 14 species of Manfreda in Guerrero (Appendix 1). We corroborated the taxonomic identifications and georeferenced $52 \%$ of all records that lacked geographic coordinates. Manfreda collections in Guerrero are limited to 33 of the 81 municipalities in the state. The records and richness by municipalities are concentrated in Chilpancingo de Los Bravo (18 records / 5 spp.), Taxco de Alarcón (8 records / 3 spp.), Chilapa de Álvarez (7 records / 4 spp.), and Leonardo Bravo ( 7 records / 3 spp.). On the other hand, in Arcelia, Chilapa de Álvarez, Colotlipa, Carrizal de Bravo, Guayameo, Leonardo Bravo, Taxco de Alarcón, Técpan de Galeana, Tzitzio, and Zirándaro are restricted five endemic species to Guerrero (M. arceliensis Art.Castro, J.G. Zavala \& Cruz Durán, M. bulbulifera Castillejos \& E. Solano, M. guerrerensis Matuda, M. justosierrana GarcíaMend., and M. parva Aaron Rodr.; Table 1).

Manfreda species in Guerrero have been collected mostly in temperate and cold conditions with coniferous, oak-pine, oak, and pine forest, where 13 species are located: M. arceliensis, M. bulbulifera, M. chamelensis E.J. Lott \& Verh.-Will., M. guerrerensis, M. hauniensis (J.B. Peterson) Verh.-Will., M. aff. jaliscana Rose, M. justosierrana, M. maculata (C. Mart.) Rose, M. parva, M. pringlei Rose, M. pubescens (Regel \& Ortgies) Verh.-Will. ex Piña, M. scabra (Ort.) McVaugh, and M. umbrophila GarcíaMend. Meanwhile, in warm climatic conditions with tropical deciduous forest, as in subdeciduous tropical forest, savannoid vegetation, and palmar, it is possible to locate: M. chamelensis, M. hauniensis, M. littoralis García-Mend., A. Castañeda \& S. Franco, M. maculata, M. pubescens, and M. scabra (Table 1).

The elevation range in which Manfreda has been collected in Guerrero is wide, from $15-450 \mathrm{~m}$ in Acapulco, Ajuchitlán del Progreso, José Azueta, and Técpan de
Galeana [M. chamelensis, M. littoralis and M. scabra]; to 1,900-2,628 m in Alpoyeca, Atilxtac, Atoyac de Alvarez, Carrizal de Bravo, Chichihualco, Chilapa de Álvarez, Eduardo Neri, Leonardo Bravo, Metlaltónoc, Taxco de Alarcón, and Técpan de Galeana $[M$. guerrerensis, M. hauniensis, M. justosierrana, M. pringlei, M. scabra, M. pubescens, and M. umbrophila].

According to Morrone et al. (2017) biogeographic provinces in Guerrero, Manfreda has been collected in the Sierra Madre del Sur (37 records / 10 spp.), Balsas Basin (26 records / 9 spp.), Transmexican Volcanic Belt (8 records / 4 spp.), and Pacific Lowlands (8 records / 3 spp.) (Figure 1).

In the grid analysis, 34 cells had at least one record, that is, $\pm 7 \%$ of the analyzed area. The number of species per cell varied from one to four, but just two cells contained four species. In the first of these cells inhabit Manfreda aff. jaliscana, M. justosierrana, M. maculata, and $M$. pringlei. While M. guerrerensis, M. justosierrana, M. pringlei, and $M$. pubescens were found in the second cell. In general, Manfreda richness is concentrated in 8 cells located in the municipalities Chilpancingo de los Bravo, Leonardo Bravo and Taxco de Alarcón, which are in the Balsas Basin, Sierra Madre del Sur, and Transmexican Volcanic Belt biographical provinces, and bring together nine species (Figure 1).

\section{Discussion}

As might be expected, the Manfreda species richness distribution patterns in Guerrero are similar to those patterns found in other angiosperm groups. For example, there is a geographical correspondence between Manfreda richness areas in Guerrero and the diversity and endemism patterns for another 507 species of Mesoamerican geophyte monocots (Sosa \& Loera 2017). Moreover, the same areas identified here are also associated with a high degree of richness, endemism and conservation priority for other plant groups; such as the perennial herbs species of Cosmos section Discopoda (DC.) Sherff (Vargas-Amado et al. 2013, 2019), bulbous herbaceous of Iridaceae tribe Tigridieae (Munguía-Lino et al. 2016), 79 species of the genus Salvia L. (Martínez-Gordillo et al. 2016) and the areas of endemism found for 32 taxa restricted to the Sierra Madre del Sur (Santiago-Alvarado et al. 2016).

The greatest species richness of Manfreda in Mexico is found in Guerrero, wherein 14 species have been registered and five are endemic (Castro-Castro et al. 2017, 2018; Table 1). The relatively low number of collections for the genus, which have been carried out in a period of just less than 100 years (1926-2014), is striking. Manfreda collections in Guerrero are limited to 33 of the 81 municipalities in the state, $40.7 \%$ of the political territory of the state. Given the high diversity of Manfreda in 
Manfreda (Asparagaceae) in Guerrero, Mexico

Table 1. Diversity and distribution of the genus Manfreda in Guerrero, Mexico.

\begin{tabular}{|c|c|c|c|c|}
\hline Species & Distribution in Mexico & Municipalities and records & $\begin{array}{l}\text { Elevation } \\
\text { range }\end{array}$ & Vegetation types \\
\hline $\begin{array}{l}\text { 1. M. arceliensis Art.Castro, } \\
\text { J.G. Zavala \& Cruz } \\
\text { Durán }\end{array}$ & Guerrero & Arcelia (2) & $1,248-1,393$ & Oak forest \\
\hline $\begin{array}{l}\text { 2. M. bulbulifera Castillejos } \\
\text { \& E.Solano }\end{array}$ & Guerrero & Chilapa de Álvarez (1), Colotlipa (3) & $1,200-1,283$ & Pine-oak forest \\
\hline $\begin{array}{l}\text { 3. M. chamelensis E.J.Lott } \\
\text { \& Verh.-Will. }\end{array}$ & Guerrero, Jalisco & José Azueta (2), Técpan de Galeana (2) & $15-860$ & $\begin{array}{l}\text { Tropical deciduous } \\
\text { forest, pine forest }\end{array}$ \\
\hline 4. M. guerrerensis Matuda & Guerrero & $\begin{array}{c}\text { Carrizal de Bravo (1), Guayameo (1), } \\
\text { Zirándaro (1) }\end{array}$ & $950-2,300$ & Oak forest \\
\hline $\begin{array}{l}\text { M. hauniensis (J.B. } \\
\text { Petersen) Verh.-Will. }\end{array}$ & $\begin{array}{l}\text { Estado de México, } \\
\text { Guerrero, Morelos, } \\
\text { Oaxaca }\end{array}$ & $\begin{array}{c}\text { Alpoyeca (1) Atlixtac (1), Atoyac de } \\
\text { Álvarez (2), Chilpancingo de los Bravo } \\
\text { (9), Eduardo Neri (1), Malinaltepec (1), } \\
\text { Metlatonoc (1), San Miguel Totolapan (1), } \\
\text { Xochihuehuetlán (1) }\end{array}$ & $545-2,628$ & $\begin{array}{l}\text { Oak-pine forest, } \\
\text { tropical deciduous } \\
\text { and sub deciduous } \\
\text { forest }\end{array}$ \\
\hline 6. M. aff. jaliscana Rose & $\begin{array}{l}\text { Durango, Guerrero, } \\
\text { Jalisco, Michoacán, } \\
\text { Nayarit, Sinaloa, Sonora, } \\
\text { Zacatecas }\end{array}$ & $\begin{array}{l}\text { Chilpancigo de los Bravo (3), Eduardo } \\
\text { Neri (1), Tixtla de Guerrero (1) }\end{array}$ & $650-1,600$ & $\begin{array}{l}\text { Oak forest, tropical } \\
\text { deciduous forest }\end{array}$ \\
\hline $\begin{array}{l}\text { 7. M. justosierrana García- } \\
\text { Mend. }\end{array}$ & Guerrero & $\begin{array}{l}\text { Leonardo Bravo (2), Técpan de Galeana } \\
\text { (1) }\end{array}$ & $1,940-2,328$ & Oak-pine forest \\
\hline $\begin{array}{l}\text { 8. M. littoralis García- } \\
\text { Mend., A.Castañeda \& } \\
\text { S.Franco }\end{array}$ & Guerrero, Oaxaca & Acapulco (3) & $220-406$ & $\begin{array}{c}\text { Tropical deciduous } \\
\text { forest }\end{array}$ \\
\hline $\begin{array}{l}\text { 9. M. maculata (C. Mart.) } \\
\text { Rose }\end{array}$ & $\begin{array}{l}\text { Estado de México, } \\
\text { Guerrero, Oaxaca }\end{array}$ & $\begin{array}{l}\text { Chilpancingo de los Bravo (1), Iguala de } \\
\text { la Independencia (1), Taxco de Alarcón } \\
\text { (1) }\end{array}$ & $1,000-1,850$ & $\begin{array}{l}\text { Pine-oak forest, } \\
\text { tropical deciduous } \\
\text { forest }\end{array}$ \\
\hline 10. M. parva Aarón Rodr. & Guerrero & Taxco de Alarcón (4) & $1,818-1,845$ & $\begin{array}{l}\text { Coniferous forest, } \\
\text { pine-oak forest }\end{array}$ \\
\hline 11. M. pringlei Rose & $\begin{array}{l}\text { Ciudad de México, Estado } \\
\text { de México, Guerrero, } \\
\text { Hidalgo, Jalisco, } \\
\text { Michoacán, Morelos, } \\
\text { Oaxaca, Puebla, Tlaxcala, } \\
\text { Veracruz }\end{array}$ & $\begin{array}{c}\text { Chichihualco (3), Coahuayutla de José } \\
\text { María Izazaga (1), Leonardo Bravo (1), } \\
\text { Mochitlán (1) }\end{array}$ & $850-2,450$ & $\begin{array}{l}\text { Cloud forest, oak- } \\
\text { pine forest, tropical } \\
\text { deciduous forest }\end{array}$ \\
\hline $\begin{array}{l}\text { 12. M. pubescens (Regel \& } \\
\text { Ortgies) Verh.-Will. ex } \\
\text { Piña }\end{array}$ & $\begin{array}{l}\text { Chiapas, Guerrero, } \\
\text { Morelos, Oaxaca, Puebla }\end{array}$ & $\begin{array}{l}\text { Buenavista de Cuéllar (4), Chilapa de } \\
\text { Álvarez (1), Chilpancingo de los Bravo } \\
\text { (1), Iguala de la Independencia (1), } \\
\text { Leonardo Bravo (1), Pilcaya (1), Taxco de } \\
\text { Alarcón (3), Tlapa de Comonfort (1) }\end{array}$ & $800-2,420$ & $\begin{array}{l}\text { Oak-pine forest, } \\
\text { palmar, savannoid } \\
\text { vegetation, tropical } \\
\text { deciduous forest }\end{array}$ \\
\hline $\begin{array}{l}\text { 13. M. scabra (Ortega) } \\
\text { McVaugh }\end{array}$ & $\begin{array}{l}\text { Aguascalientes, Chiapas, } \\
\text { Colima, Distrito Federal, } \\
\text { Durango, Estado de } \\
\text { México, Guerrero, } \\
\text { Hidalgo, Jalisco, } \\
\text { Michoacán, Morelos, } \\
\text { Nayarit, Oaxaca, Puebla, } \\
\text { Querétaro, San Luis } \\
\text { Potosí, Veracruz, } \\
\text { Zacatecas }\end{array}$ & $\begin{array}{l}\text { Ajuchitlán del Progreso (2), Arcelia (1), } \\
\text { Azoyú (1), Chichihualco (1), Chilapa de } \\
\text { Álvarez (2), Chilpancingo de los Bravo } \\
\text { (4), Coyuca de Benítez (2), Eduardo Neri } \\
\text { (1), Iguala de la Independencia (2), Mártir } \\
\text { de Cuilapan (1) }\end{array}$ & $362-2,010$ & $\begin{array}{l}\text { Oak-pine forest, } \\
\text { tropical deciduous } \\
\text { forest }\end{array}$ \\
\hline $\begin{array}{l}\text { 14. M. umbrophila García- } \\
\text { Mend. }\end{array}$ & Guerrero, Oaxaca & Chilapa de Álvarez (3) & $1,860-1,950$ & Oak-pine forest \\
\hline
\end{tabular}


Guerrero, the elevated endemism and the low coverage of botanical explorations focus on this group in the state, current estimates of species diversity are likely underestimates and new species are likely to be found. For example, although in Guerrero the greatest diversity of Manfreda has been found in temperate and cold environments, it is advisable to focus on the collection efforts towards the tropical areas of Pacific Lowlands, since according to Castro-Castro et al. (2017, 2018), in this province is where the genus Manfreda has its highest species richness in Mexico. A final recommendation in this regard, is the detailed review of the plants included as $M$. aff. jaliscana. The six specimens analyzed show a homogeneous morphology among them, but contrasting in the sizes of the leaves, flowers and filaments with respect to other specimens collected in western and northwestern Mexico, the area where the species was described ( $\underline{1903}$ ), and it has been reported more frequently (CastroCastro et al. 2017). In addition, the phenology of the populations of Guerrero differs in what is known for
M. jaliscana, which has been reported in bloom mostly during the dry period (see Appendix 1 and Rodríguez \& Castro-Castro 2007).

During the present investigation it was possible to detect another set of specimens that could not be assigned to any of the known species in Manfreda. The plants were collected in the municipality of Arcelia, an area where only two specimens of the genus had been previously collected before 2006 (Appendix 1). Given the general morphology, these plants could be related to M. maculata and M. parva. However, there are multiple differences that allow them to be recognized as an undescribed species. These dissimilarities and similitudes are detailed in the following lines together with data on the ecological preferences, taxonomic notes of the new species and a key for the identification of Manfreda in Guerrero.

Taxonomic treatment. Manfreda arceliensis Art.Castro, J.G. Zavala \& Cruz Durán sp. nov. (Figure 2).

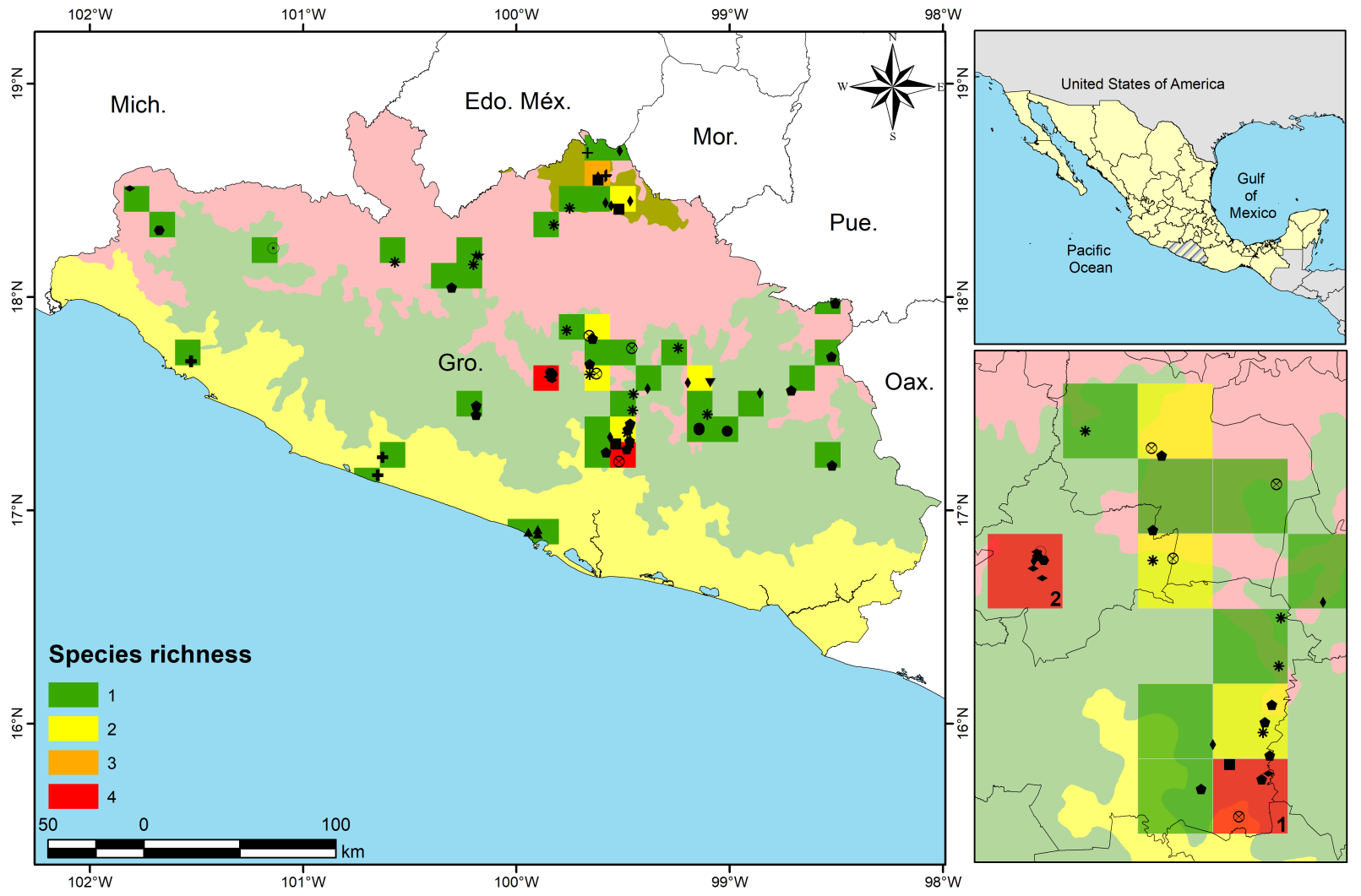

Biogeographic provinces

\section{Species}

- M.aff. jaliscana

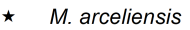

- M. bulbulifera

+ M. chamelensis
Sierra Madre del Sur
Transmexican Volcanic Belt

Figure 1. Species richness of Manfreda in Guerrero, Mexico. In the cutout of the lower right corner, the two cells with the greatest richness are indicated. The grid comprises cells with an area of $144 \mathrm{~km}^{2}$. Biogeographical regionalization according to Morrone et al. (2017). 


\section{Manfreda (Asparagaceae) in Guerrero, Mexico}

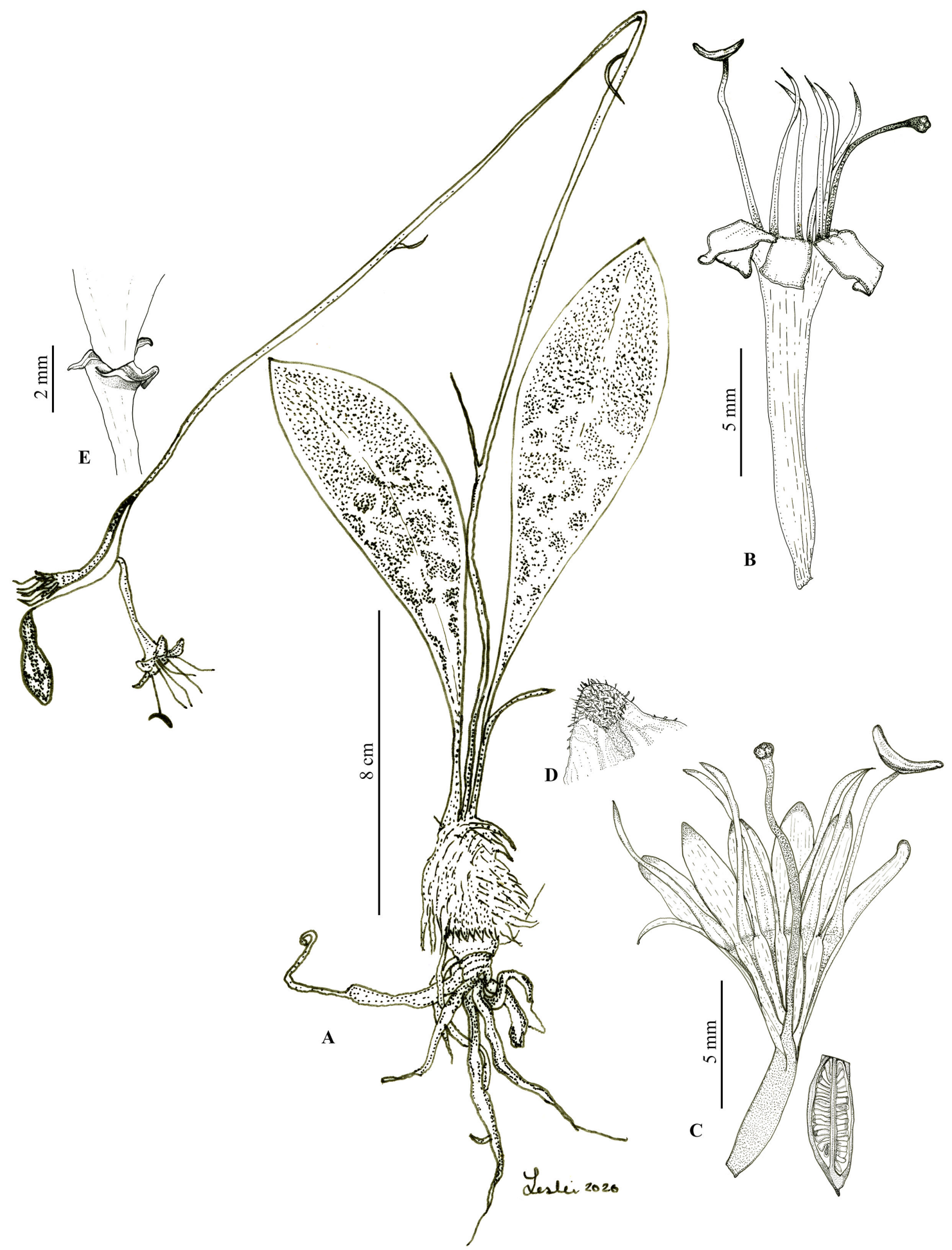

Figure 2. Manfreda arceliensis Art.Castro, J.G. Zavala \& Cruz Durán. A. Habit. B. Lateral view of flower. C. Perigone dissection and ovary longitudinal section. D. Detail of the tuft of short hairs on the top of perigone lobes. E. Floral bract and bracteoles. Illustrated by Lesslie Martínez Rubí. 
Type: Mexico. Guerrero: Arcelia municipality, Filo del Cerro el Tepehuaje, Campo Morado, 1393 m, 19 July 2006 (fl), R. Cruz-Durán et al. 6428 (Holotype: FCME; Isotype: CIIDIR).

Diagnosis. Manfreda arceliensis is morphologically similar to M. maculata and M. parva, but it can be distinguished from the former by the herbaceous leaves, broadly oblanceolate, flat, and glabrous (vs. coriaceous, lanceolate to oblanceolate, slightly channeled, undulate, and densely pubescent on both faces), inflorescence $41-52 \mathrm{~cm}$ long with 2-4 flowers [vs. (30-) 60-120 cm long with 6-22 flowers], first sterile bracts $1.4-3.3 \mathrm{~cm}$ long (vs. $4.5-8.5 \mathrm{~cm}$ long), perigone funnel-shaped (vs. tubular), and filaments inserted $5-5.2 \mathrm{~mm}$ below the sinuses of the lobes (vs. $6-10 \mathrm{~mm}$ ). For its part, it distinguishes from $M$. parva for developing a bulb ovoid, 3-3.8 $\times 2.3-2.7 \mathrm{~cm}$ (vs. oblong, 2-2.5 $\times 1-2 \mathrm{~cm}$ ), leaves $2-3$, broadly oblanceolate, flat, green with densely purple spots [vs. (5-)11-24, linear, channeled, green concolorous], inflorescence with 3-4 flowers [vs. (4-)9-15], peduncle $38-48 \mathrm{~cm}$ long with 3-4 bracts (vs. peduncle 19$26 \mathrm{~cm}$ long with $4-7$ bracts), and the first sterile bracts linear, $1.4-3.3 \times 0.12-0.25 \mathrm{~cm}$ (vs. lanceolate, $6-8 \times 0.7$ $1 \mathrm{~cm})$.

Perennial herb, 42-52 cm tall. Corm ovoid 3-3.8 $\times 2.3-$ $2.7 \mathrm{~cm}$, with small buds and thickened, contractile and fleshy roots. Roots filiform, 3.5-6.5 cm long. Bulb ovoid, 3-3.8 $\times 2.3-2.7 \mathrm{~cm}$, tunicate, straw. Leaves $2-3$ in a basal rosette, alternate, broadly oblanceolate, $10-14.5 \times 1.9-4 \mathrm{~cm}$, erect, flat, thin to leathery, green with densely purple spots, upper and lower surface tiny papillate, acute and soft apex, narrowed into a basal petiolar portion, margin hyaline, smooth. Inflorescence spiciform, $41-52 \mathrm{~cm}$ long, erect, arcuate apex, internodes decreasing in length towards the apex; peduncle $38-48 \mathrm{~cm}$ long, bracts $3-4$, first sterile bracts linear, $14-33 \times 1.2-2.5 \mathrm{~mm}$, the closest to the rachis $6.6-$ $7 \times 0.4-0.7 \mathrm{~mm}$, both acute, truncate, clasping, thin, brownish green, concolorous, upper and lower surface smooth, hyaline, adpressed to divaricate; rachis lax, 1-2.6(-4.5) cm long, with 2-4 floral nodes, internodes 1.2$3 \mathrm{~cm}$ long, primary floral bracts linear, 1.6-4.4 $\times 0.5$ $0.6 \mathrm{~mm}$, acute, truncate, smooth, persistent, yellow-brow, erect or reflexed. Bracteoles 1 at each floral node, ensiform to acicular, $0.8-1.1 \times 0.1-0.2 \mathrm{~mm}$, entire, yellow-brow. Flowers actinomorphic, funnel-shaped, ascending, yellowish green and with dense and fine points of reddish purple on the outside and yellow pale inside in anthesis; perigone tube $1.5-1.8 \mathrm{~cm}$ long, $0.6-0.9 \mathrm{~cm}$ wide at the base of the lobes, tubular but widen slightly towards its distal portion, slightly curved; lobes $6.5-7.5 \times 3.6-4.4 \mathrm{~mm}$, ovatedeltate, markedly divergent to reflexed in anthesis, apices with a tuft of short white hairs. Stamens epitepalous, antitepalous, phanerantherous; filaments subulate, 1.7$1.9 \mathrm{~cm}$ long from their insertion into the perigone tube, inserted 5-5.2 $\mathrm{mm}$ below the sinuses of the lobes, yellow brown to reddish; anthers elliptic, $8-9 \times 1.5-1.8 \mathrm{~mm}$, yellow with dense and fine points of reddish purple. Ovary 7.5$9.7 \times 3.2-4 \mathrm{~mm}$, ovoid to narrowly ovoid; style filiform, $2.8-3 \mathrm{~cm}$ long in anthesis, purple, exserted from the perigone tube by $1.3-1.5 \mathrm{~cm}$ in anthesis; stigma trigonous, trilobed, papillose, clavate. Fruit unknown.

Distribution, ecology, and phenology. Manfreda arceliensis is endemic to northern Guerrero in the transition zone between Balsas Basin and Sierra Madre del Sur biogeographic provinces. It inhabits oak forest with savannoid vegetation elements; in areas with deep and acid soils at an elevation of 1,248-1,393 m. Manfreda arceliensis is associated with Byrsonima crassifolia (L.) Kunth, Cardiostigma longispatha (Herb.) Baker, Clethra hirsutovillosa S. Valencia \& Cruz Durán, Dodonaea viscosa Jacq., Psidium sp. and Quercus magnoliifolia Née. The species flowers in July.

Conservation status. Manfreda arceliensis is represented by two collections in close proximity. The EOO was of $0.76 \mathrm{~km}^{2}$, and the size of the AOO is $8 \mathrm{~km}^{2}$, based on cells of $2 \times 2 \mathrm{~km}$. Adjusting to EOO and AOO areas results and following the IUCN (2019) criteria (extent of occurrence estimated to be less than $100 \mathrm{~km}^{2}$ and known to exist at only a single location), a preliminary category of Critically Endangered is proposed (CR/B1a and B2a). It is advisable to perform additional explorations and collections in the area where the species is found.

Etymology. The name of the new species refers to the municipality of Arcelia, Guerrero, Mexico.

Additional specimens examined. Mexico. Guerrero: Arcelia municipality, cerca de la cañada El Limón, Campo Morado, 1,248 m, 17 July 2006 (fl), R. Cruz-Durán et al. 6287 (CIIDIR, FCME).

Relationship and taxonomic position. Manfreda arceliensis is the smallest species among all the taxa of the genus present in Guerrero. Moreover, it is the species that develops fewer flowers in Manfreda. Morphologically, M. arceliensis is similar to M. maculata and M. parva, the differences and similarities in morphological traits among these three species are highlighted in the diagnosis and the key for Manfreda in Guerrero provided below. 


\section{Key for Manfreda in Guerrero, Mexico}

1. Perigone tube $0.5-2.8 \mathrm{~mm}$ long

1. Perigone tube $6-33 \mathrm{~mm}$ long

2. Leaves 9-27 $\times 2-6 \mathrm{~cm}$, elliptic to lanceolate-elliptic, flat, green concolorous; perigone lobes $2.5-3.5 \mathrm{~cm}$ long, linear, reflexed; filaments $1.3-2.1 \mathrm{~cm}$ long

M. littoralis

2. Leaves 12-25 × 0.3-0.6 cm, linear to lanceolate, channeled, green with purple macules; perigone lobes $0.8-1.1 \mathrm{~cm}$ long, linear-oblong, erect to reflexed; filaments $5-6.5 \mathrm{~cm}$ long M. bulbulifera

3. Leaves pubescent 4

3. Leaves glabrous

4. Filaments $1.7-2.2 \mathrm{~cm}$ long M. maculata

4. Filaments $3.5-5.2 \mathrm{~cm}$ long 5

5. Leaves 2-3, 20-45 $\times 6-8 \mathrm{~cm}$, markedly narrowed and pubescent toward the blade base ....... M. guerrerensis 5. Leaves $3-5(-9), 18-28(-70) \times 2.2-4.2(-6) \mathrm{cm}$, not markedly narrowed toward the base and, densely pubescent on the entire surface M. pubescens

6. Rachis dense, internodes $0-1 \mathrm{~cm}$ long 7

6. Rachis lax, internodes $1.2-4(-6) \mathrm{cm}$ long 8 7. Corm 3-5 × 1.5-2.5 cm; leaves 15-56(-80) $\times$ 0.8-2.8 cm, dark green; filaments $2.6-4.5(-5.4) \mathrm{cm}$ long M. pringlei

7. Corm (4-)8-10 × (1.5-)2-3.5 cm; leaves (25-)35-45 $\times(5-) 7-10 \mathrm{~cm}$, light green, lustrous, with dark macules; filaments (4.5-)7-8.5 cm long ..... M. umbrophila

8. Plants flowering from January to May, during the dry season M. chamelensis

8. Plants flowering from July to November, mainly during the rainy season ... 9

9. Plants (1-)1.5-3.8 $\mathrm{m}$ tall 10

9. Plants $0.4-0.6 \mathrm{~m}$ tall 12

10. Leave margin irregularly denticulate to denticulate-erose, the teeth small and simple to large and bifid or trifid; inflorescence 2-3.8 $\mathrm{m}$ tall; filaments exceeding the tube by $6.3-10.5 \mathrm{~cm}$ M. hauniensis

10. Leave margin whole to papillose; inflorescence 1.4-2.5 m tall; filaments exceeding the tube by $3-5.5 \mathrm{~cm}$ 11

11. Leaves widely oblong to elliptical, coriaceous; basal peduncle bracts similar in shape and size to the leaves; flowers sessile to pedicellate; filaments inserted $1 / 3$ to $1 / 5$ from top of the tube or just in the tube mouth .... M. scabra

11. Leaves linear-lanceolate, coriaceous to herbaceous; basal peduncle bracts clearly shorter than the leaves; flowers sessile; filaments inserted 1/4 from top of the tube M. justosierrana

12. Bulb ovoid, 3-3.8 × 2.3-2.7 cm; leaves 2-3, broadly oblanceolate, flat, green with densely purple spots; inflorescence with 2-4 flowers; peduncle $38-48 \mathrm{~cm}$ long, sterile bracts $3-4$, the first one linear, 1.4-3.3 $\times 0.12-0.25$ $\mathrm{cm}$ M. arceliensis

12. Bulb oblong, 2-2.5 × 1-2 cm; leaves (5-)11-24, linear, channeled, green concolorous; inflorescence with (4-)9-15 flowers; peduncle 19-26 cm long, sterile bracts $4-7$, the first one lanceolate, $6-8 \times 0.7-1 \mathrm{~cm} \ldots M$. parva 


\section{Acknowledgments}

We are grateful to the curators and staff of herbaria who contributed collections. We appreciate Lesslie Martínez Rubí for contributing illustrations with great detail. Thank you to Isaac Marck and Emilio A. Castro Martínez for reviewing the initial version of the manuscript.

\section{Literature cited}

Ayala-Hernández MM. 2006. Patrones de diversidad y distribución del género Manfreda Salisb. Agavaceae. BSc Thesis. Universidad Nacional Autónoma de México.

Bachman S, Moat J, Hill A, de la Torre J, Scott B. 2011. Supporting red list threat assessments with GeoCAT: Geospatial conservation assessment tool. ZooKeys 150: 111-126. DOI: http://dx.doi.org/10.3897/zookeys.150.2 109

Castillejos-Cruz C. 2009. Sistemática del género Manfrea Salisb. (Agavaceae). $\mathrm{PhD}$ Thesis. Colegio de Postgraduados.

Castro-Castro A, Munguía-Lino G, Carrillo-Reyes P, Rodríguez A. 2017. Manfreda occidentalis (Agavoideae, Asparagaceae) a new species from western Mexico. Phytotaxa 321: 60-70. DOI: http://dx.doi.org/10.11646/ phytotaxa.321.1.2

Castro-Castro A, Zamora-Tavares P, Carrillo-Reyes P, Rodríguez A. 2018. Manfreda santana-michelii (Asparagaceae Subfamily Agavoideae), a striking new species from Sierra Madre del Sur in western Mexico. Systematic Botany 43: 497-501. DOI: http://dx.doi.org/ 10.1600/036364418X697229

ESRI [Environmental Systems Research Institute]. 2014. ArcView GIS ver. 10.3. Redlands, California.

García-Mendoza AJ. 2011. Tres especies nuevas de Manfreda (Agavaceae) del sur de México. Revista Mexicana de Biodiversidad 82: 747-757. DOI: https:// doi.org/10.22201/ib.20078706e.2011.3.731

Gries C, Gilbert EE, Franz NM. 2014. Symbiota - A virtual platform for creating voucher-based biodiversity information communities. Biodiversity Data Journal 2: e1114. DOI: https://doi.org/10.3897/BDJ.2.e1114

Hijmans RJ, Guarino L, Bussink C, Mathur P, Cruz M, Berrantes I, Rojas E. 2004. DIVA-GIS ver. 4. Un Sistema de Información Geográfica para el Análisis de Distribución de Especies: Manual. Lima, Peru: Centro Internacional de la Papa, Instituto Internacional de Recursos Genéticos Vegetales.

IUCN. 2019. Guidelines for Using the IUCN Red List Categories and Criteria. Version 14. Standards and Petitions Committee. http://www.iucnredlist.org/docum ents/RedListGuidelines.pdf (accessed May 20, 2020)

Martínez-Gordillo M, Fragoso-Martínez I, LeautaudValenzuela P, Ginez-Valenzuela L, Martínez-Ambriz E, Méndez-Sólis V. 2016. Diversidad y endemismo del género Salvia (Lamiaceae) en la Sierra Madre del Sur de
Guerrero, México. In: Luna-Vega I, Espinosa D, Contreras-Medina R, eds. Biodiversidad de la Sierra Madre del Sur. Ciudad de México: Universidad Nacional Autónoma de México, pp. 177-191. ISBN: 978-607-02-7906-5

Matuda E. 1975. Una nueva Manfreda de Guerrero. Cactáceas y Suculentas Mexicanas 20: 46-48.

McVaugh R. 1989. Flora Novo-Galiciana (Bromeliaceae to Dioscoreaceae) Vol. 15 . Michigan, EUA: The University of Michigan Herbarium, Ann Arbor. ISBN: 0-9620733-0-X.

Morrone JJ, Escalante T, Rodríguez-Tapia G. 2017. Mexican biogeographic provinces: Map and shapefiles. Zootaxa 4277: 277-279. DOI: https://doi.org/10.11646/ zootaxa.4277.2.8

Munguía-Lino G, Escalante T, Morrone JJ, Rodríguez A. 2016. Areas of endemism of the North American species of Tigridieae (Iridaceae). Australian Systematic Botany 29: 142-156. DOI: https://doi.org/10.1071/SB16002

Piña LI. 1985a. Consideraciones sobre el género Manfreda I. Cactáceas y Suculentas Mexicanas 30: 27-32.

Piña LI. 1985b. Consideraciones sobre el género Manfreda II. Cactáceas y Suculentas Mexicanas 30: 56-64.

Piña LI. 1985c. Consideraciones sobre el género Manfreda III. Cactáceas y Suculentas Mexicanas 30: 84-90.

Piña LI. 1986. Consideraciones sobre el género Manfreda IV. Cactáceas y Suculentas Mexicanas 31: 12-18.

Rodríguez A, Castro-Castro A. 2007. Potencial ornamental de los "amoles" (Manfreda, Agavaceae) en México. Ibugana 15: 3-11.

Rodríguez A. 2009. Manfreda parva (Agavaceae) especie nueva del estado de Guerrero, México. Acta Botanica Mexicana 88: 1-8. DOI: https://doi.org/10.21829/abm $\underline{88.2009 .309}$

Rose JN. 1903. Studies of Mexican and Central American plants No. 3. Contributions from the United States National Herbarium 8: 1-339.

Rzedowski J. 1990. Vegetación potencial. Atlas Nacional de México. Catálogo de metadatos geográficos. Comisión Nacional para el Conocimiento y Uso de la Biodiversidad. http://www.conabio.gob.mx/informacion/ gis/ (accessed: May 20, 2020).

Santiago-Alvarado M, Montaño-Arias G, Espinosa D. 2016. Áreas de endemismo de la Sierra Madre del Sur. In: Luna-Vega I, Espinosa D, Contreras-Medina R, eds. Biodiversidad de la Sierra Madre del Sur. Ciudad de México: Universidad Nacional Autónoma de México , pp. 431-448. ISBN: 978-607-02-7906-5

Simpson MG. 2006. Plant Systematics. USA, Massachusetts: Elsevier Academic Press. ISBN: 0-12-644460-9

Sosa V, Loera I. 2017. Influence of current climate, historical climate stability and topography on species richness and endemism in Mesoamerican geophyte plants. PeerJ 5: e3932. DOI: https://doi.org/10.7717/ peerj.3932 


\section{Manfreda (Asparagaceae) in Guerrero, Mexico}

Suárez-Mota ME, Villaseñor JL. 2011. Las Compuestas endémicas de Oaxaca, México: diversidad y distribución. Boletín de la Sociedad Botánica de México 88: 55-66. DOI: https://doi.org/10.17129/botsci.308

Thiers B. 2019. Index Herbariorum: A global directory of public herbaria and associated staff. New York: New York Botanical Garden's Virtual Herbarium. http://swe etgum.nybg.org/science/ih/ (accessed January 27, 2020).

Vargas-Amado G, Castro-Castro A, Harker M, Villaseñor JL, Ortiz E, Rodríguez A. 2013. Distribución geográfica y riqueza del género Cosmos (Asteraceae: Coreopsideae). Revista Mexicana de Biodiversidad 84: 536-555. DOI: https://doi.org/10.7550/rmb.31481

Vargas-Amado G, Castro-Castro A, Harker M, VargasAmado ME, Villaseñor JL, Ortiz E, Rodríguez A. 2019. Western Mexico is a priority area for the conservation of
Cosmos (Coreopsideae, Asteraceae), based on richness and track analysis. Biodiversity and Conservation 29: 545-569. DOI: https://doi.org/10.1007/s10531-019-0189 $\underline{8-2}$

Verhoek-Williams SE. 1975. A study of the tribe Poliantheae (including Manfreda) and revisions of Manfreda and Prochnyanthes (Agavaceae). PhD Thesis. Cornell University.

Verhoek S. 1978. Huaco and amole: a survey of the uses of Manfreda and Prochnyanthes. Economic Botany 32: 124-130. DOI: https://doi.org/10.1007/BF02866866

Willis F, Moat J, Paton A. 2003. Defining a role for herbarium data in Red List assessments: a case study of Plectranthus from eastern and southern tropical Africa. Biodiversity and Conservation 12: 1537-1552. DOI: https://doi.org/10.1023/A:1023679329093
Associate editor: Eduardo Ruiz Sánchez

Author contributions: ACC designed the study and compilation of the database. ACC, JGZP and RCD performed the field work, herbaria revisions, geographic analyses, and wrote the manuscript. All authors reviewed and accepted the final version of the document. 
Appendix 1. Examined materials of the genus Manfreda in Guerrero, Mexico.

M. bulbulifera. Chilapa de Álvarez municipality: $32 \mathrm{~km}$ al sureste de Colotlipa, $17 \mathrm{~km}$ al E de Tlanicuilulco, $7 \mathrm{~km}$ al E de El Epazote y $1 \mathrm{~km}$ al E de Popocatzin, 1,283 m, 28 July 2008, A. Rodríguez \& L.F. Pérez-Alvarez 5521 (IBUG). Colotlipa municipality: $8 \mathrm{mi}$ al SE de Colotlipa, G.F. Rhymes \& C.M. Rowell 3855 (MICH); $8 \mathrm{mi}$ al SE de Colotlipa, H.D. Irby \& C.M. Rowell 3571 (MICH); camino de terracería al SE de Colotlipa, entre El Epazote y Mexcalcingo, 1,258 m, 8 July 2006, C. Castillejos-Cruz et al. 1807 (CHAPA, FEZA, IEB, MICH, NY, US).

M. chamelensis. José Azueta municipality: $1.6 \mathrm{~km}$ al SO del Caserio "La Vainilla", cerros que limitan la "Mesa del Mango", 400 m, 9 December 1991, C. Gallardo et al. 745 (FCME); $2 \mathrm{~km}$ al Suroeste del caserío de la Vainilla (Plantas del Parque Ecológico La Vainilla, $8 \mathrm{~km}$ al Norte de Zihuatanejo, Guerrero), 360 m, 8 December 1992, C. Gallardo et al. $745 a$ (MEXU). Técpan de Galeana municipality: cerca de la Laguna de los Colches por la entrada a Costa Azul, 15 m, 30 November 1990, F. Lorea 5378 (FCME, MEXU); without data, 860 m, 1 November 1991, N. Diego 6310 (FCME, MEXU).

M. guerrerensis. Carrizal de Bravo municipality: Filo de Caballos, 2,300 m, 24 September 2004, E. Solano et al. 1723 (FEZA). Guayameo municipality: $7 \mathrm{~km}$ al SW de San Rafael, $950 \mathrm{~m}, 24$ November 1973, J. González-Medrano 6517 (MEXU). Zirándaro municipality: San Rafael, km 490 de la brecha Placeres del Oro-Guayameo, $8 \mathrm{~km}$ al S de Las Guacamayas, $950 \mathrm{~m}$, 27 September 2010, A. Castro-Castro et al. 2260 (IBUG).

M. hauniensis. Alpoyeca municipality: aprox. $9 \mathrm{~km}$ al $\mathrm{N}$ de Zapotitlán Lagunas, de la carr. Tlapa-Huamuxtitlán, 2,300 m, 26 August 1999, R.J. Santana 726 (FCME). Atlixtac municipality: km 18-19 de Tlatlauquitepec a Tlacoapa, 2,270 m, 28 August 1999, R. Fragoso \& R.J. Santana 1462 (FCME). Atoyac de Álvarez municipality: km 1.5 de la brecha a Toro Muerto, a partir de la carr. Atoyac-Filo de Caballo, Ejido El Molote, 2628 m, 29 October 2012, A. Castro-Castro et al. 3098 (IBUG, MEXU); $25 \mathrm{~km}$ al NE de Paraíso, carretera a Atoyac-Puerto del Gallo, 1,640 m, 5 September 1983, J.C. Soto-Núñez et al. 5240 (MEXU). Chilpancingo de los Bravo municipality: $5.2 \mathrm{~km}$ al W del Ocotito, camino a Jaleaca, $735 \mathrm{~m}, 10$ November 1982, R. Torres et al. 1832 (MEXU); barranca a $1 \mathrm{~km}$ al N de Xochipala, 1,200 m, 22 November 1988, A. García-Mendoza et al. 4095 (MEXU); Palo Blanco, 1185 m, 20 October 2007, A. Almazán 770 (FCME); Rincón de la Vía, 700 m, 19 November 1961, H. Kruse 691 (MEXU); ibid., 20 November 1973, H. Kruse 19731129-218 (MEXU); ibid., 800 m, 3 November 1973, H. Kruse 19731103-219 (MEXU); ibid., 999 m, 27 December 1973, H. Kruse 19731227-220 (MEXU); carretera federal rumbo a Acapulco, 1,097 m, 28 October 2005, C. Castillejos-Cruz 1760 (MEXU). Eduardo Neri municipality: Xochipala, 2,200 m, 27 October 1990, A. Garcia-Mendoza 5255 (ARIZ, ASU, MEXU). Malinaltepec municipality: along highway 95, between kilometer markers 39-40, 3 miles north of El Rincón, 15 miles north of Tierra Colorada, 1,500 m, 15 January 1979, T.B. Croat 45691 (MEXU). Metlatonoc municipality: camino entre Zitlaltepec y San Miguel Amoltepec, 1,900 m, 29 June 2005, R.M. Fonseca \& E. Velazquez 3241 (FCME). San Miguel Totolapan municipality: Los Cajones, 545 m, 15 January 1989, L.C. Rodríguez-Muñoz 418 (MEXU). Xochihuehuetlán municipality: cañada Las Pozas, $3.25 \mathrm{~km}$ al NO de Jilotepec, cerro Xilotzin, 1,410 m, 18 September 1995, E. Moreno-Gutiérrez 1131 (MEXU).

M. aff. jaliscana Rose. Chilpancingo de los Bravo municipality: El Ocotito-Jaleaca gap, ca. km 5, 650 m, 21 July 1991, L.M. González-Villarreal et al. 4353 (WIS); Rincón de la Vía, 700 m, 25 September 1961, H. Kruse 465 (FCME, MEXU); camino entre Chilpancingo y Chichihualco, 1,100 m, 1 November 2006, L. Lozada 3311 (FCME). Eduardo Neri municipality: Xochipala, 1,200 m, 14 February 1991, A. Gómez 2213 (FCME). Tixtla de Guerrero municipality: cerro a orilla de la laguna de Huitziltepec, 1,600 m, 28 August 1998, B. Ludlow \& N. Diego 428 (FCME).

M. justosierrana. Leonardo Bravo municipality: $4 \mathrm{~km}$ al E de Los Morros, $7 \mathrm{~km}$ al SE de Filo de Caballos, carr. a Xochipala, 1,940 m, 11 November 1998, A. García-Mendoza et al. 6739 (ARIZ, ASU); en las afueras de Filo de Caballo, without data, A. García-Mendoza 4400 (MEXU); $1 \mathrm{~km}$ al SO de Filo de Caballo, without data, A. Garcia-Mendoza et al. 4103 (MEXU); Chichihualulco, $1 \mathrm{~km}$ al SO de Filo de Caballo, rumbo a Carrizal de Bravo, 2328 m, 30 October 2012, A. Castro-Castro et al. 3103 (IBUG, IEB, MEXU); $2 \mathrm{~km}$ al N de Los Morros, $11 \mathrm{~km}$ al SE de Filo de Caballo, A. García-Mendoza et al. 6737 (MEXU). Técpan de Galeana municipality: Teotepec, without data, G.B. Hinton 14317 (US).

M. littoralis. Acapulco municipality: alrededores de la Zona Arqueológica Palma Sola, 406 m, 28 July 2008, A. Rodríguez \& L.F. Pérez-Álvarez 5524 (IBUG); Parque Nacional El Veladero, barranca al N de la Colonia Independencia, $220 \mathrm{~m}, 14$ August 1999, A. García-Mendoza et al. 6900 (MO); Pie de la Cuesta, $10 \mathrm{mi}$ al N de Acapulco, $240 \mathrm{~m}$, without data, H. McDaniels 174 (BHF).

M. maculata. Chilpancingo de los Bravo municipality: $3.5 \mathrm{~km}$ al SE de Soyatepec por el camino al Cerro El Toro, 1,000 m, 14 November 1987, L.C. Rodríguez 281 (FCME, MEXU). Iguala y Buenavista municipality: cañón de La Mano, entre Los Amates y El Naranjo, $10 \mathrm{~km}$ al N de Iguala por el ferrocarril, 1,000 m, 19 September 1986, C. Catalán et al. 149 (MEXU). Taxco de Alarcón municipality: Taxco, 1,850 m, 12 August 1937, R.Q. Abbot 354 (GH). 
Manfreda (Asparagaceae) in Guerrero, Mexico

M. parva. Taxco de Alarcón municipality: $3 \mathrm{~km}$ al NE de Taxco, a lo largo de la carretera de cuota, justo en el Mirador, 1,845 m, 7 September 2007, A. Rodríguez \& L.F. Pérez-Álvarez 5211 (ENCB, IEB, MEXU, WIS); $3 \mathrm{~km}$ al NE de Taxco, a lo largo de la carretera de cuota, justo en el Mirador, 1,845 m, 27 July 2008, A. Rodríguez \& L.F. Pérez-Álvarez 5518 (IBUG); Acamixtla, en la zona de bienes comunales de Acamixtla, km 4 de la carretera Méx. 95, 1,818 m, 20 July 2013, G. MunguíaLino \& A. Rodríguez 277 (IBUG); aprox. $3.5 \mathrm{~km}$ al N de Tetipac, 1840 m, 14 October 1996, I.A. Pérez-Samayoa 94 (FCME).

M. pringlei. Chichihualco municipality: a 4 km de Filo de Caballo, camino a El Carrizal, 2,350 m, 27 July 1990, A. GarcíaMendoza et al. 4848 (MEXU); Carrizalillo, $1 \mathrm{~km}$ al SO de Filo de Caballo, 2,360 m, 21 February 1988, A. García-Mendoza et al. 4102 (MEXU); entronque a las terracerías Filo de Caballo-Chichihualco-Puerto del Gallo, $2450 \mathrm{~m}, 21$ February 1988, A. García-Mendoza et al. 4109 (MEXU). Coahuayutla de José María Izazaga: La Corva, $5.12 \mathrm{~km}$ al NE, 1,060 m, 18 September 1999, J. Calónico-Soto 16078 (MEXU). Leonardo Bravo municipality: $3 \mathrm{~km}$ al O de Carrizal de Bravo, crucero a Chichihualulco, 2,540 m, 20 October 2012, A. Castro-Castro et al. 3105 (IBUG, MEXU). Mochitlán municipality: Rincón Viejo, $3 \mathrm{~km}$ al NO de Rincón de la Vía, terrenos de Huber Kruse Jr., 850 m, 18 October 1995, A. García-Mendoza et al. 6111 (MEXU).

M. pubescens. Buenavista de Cuéllar municipality: cañón de La Mano, junto a la vía del ferrocarril, 900 m, 28 November 1996, A. García-Mendoza 6385 (MEXU); cañón de La Mano, $1.5 \mathrm{~km}$ al SO de Los Amates, por la vía del ferrocarril a Los Naranjos, 900 m, 10 November 1998, A. García-Mendoza et al. 6730 (ASU, MEXU); ibid., A. García-Mendoza et al. 6732 (MEXU); ibid., A. García-Mendoza et al. 6736 (ARIZ, ASU, MEXU); at km 75 on Mexico highway 95D from Iguala to Cuernavaca, 1,000 m, 3 October 1982, H.H. Iltis et al. 28729 (WIS). Chilapa de Álvarez municipality: colectado en Chilapa Guerrero, 1800 m, July 1983, I. Piña-Luján s.n. (MEXU). Chilpancingo de los Bravo municipality: camino Soyatepec-Toro, 800 m, 14 November 1987, L.C. Rodríguez-Muñoz 281 (MEXU). Leonardo Bravo municipality: entre Filo de Caballo y Carrizal, 2420 m, 30 October 2005, R. Ríos et al. 220 (MEXU). Pilcaya municipality: km 113.5 carretera Méx. 95, $1 \mathrm{mi}$ al NW de Cacahuamilpa, 1,343 m, 29 July 2008, A. Rodríguez \& L.F. Pérez-Álvarez 5526 (IBUG). Taxco de Alarcón municipality: km 5 carretera Taxco-Tetipac, $1 \mathrm{~km}$ al S de Casahuates, $2071 \mathrm{~m}, 27$ October 2012, A. Castro-Castro et al. 3057 (IBUG, MEXU); $4 \mathrm{~km}$ al S de Taxco El Viejo, $\mathrm{km} 6$ de la carretera 56, por la brecha libre Iguala-Cuernavaca, $1202 \mathrm{~m}, 21$ July 2013, G. Munguía-Lino \& A. Rodríguez-Contreras 284 (IBUG); km 110 de la carretera Méx. 95 carretera libre Cuernavaca-Iguala, $21 \mathrm{~km}$ al S de Taxco y $8 \mathrm{~km}$ al S de Taxco El Viejo, $1031 \mathrm{~m}, 21$ July 2013, G. Munguía-Lino \& A. Rodríguez 288 (IBUG). Tlapa de Comonfort municipality: $20.1 \mathrm{~km}$ al E de Petlaltina ó $68.1 \mathrm{~km}$ al E de Chilapa, camino a Tlapa Gro., 1,700 m, 14 November 1982, R. Torres et al. 1936 (MEXU).

M. scabra. Ajuchitlán del Progreso municipality: San Antonio de los Libres, 362 m, 10 July 2014, P. Chamu-Alonso 119 (MEXU); ibid., 28 July 2014, P. Chamu-Alonso $137 b$ (MEXU). Arcelia municipality: Achotla, $600 \mathrm{~m}$, October 1926, B.P. Reko 5025 (US). Azoyú municipality: Las Parotas (Mina), 1,000 m, 6 August 1936, G.B. Hinton 9201 (RSABG, US). Chichihualco municipality: carretera a Chichí, 1,345 m, 24 September 2005, C. Castillejos-Cruz 1743 (MEXU). Chilapa de Álvarez municipality: $22 \mathrm{~km}$ delante de Atzacoaloya, 2,010 m, 4 November 1983, E. Velázquez 319 (MEXU); $1 \mathrm{~km}$ al E de Popocatzin, $7 \mathrm{~km}$ al E de El Epazote, $17 \mathrm{~km}$ al E de Tlanicuilulco y $32 \mathrm{~km}$ al SE de Colotlipa, entre El Epazote y Mexcalzingo, 1,286 m, 28 July 2008, A. Rodríguez \& L.F. Pérez-Álvarez 5520 (IBUG). Chilpancingo de los Bravo municipality: km 8 de la carretera Chilpancingo-Chilapa, frente a una ermita, 1,665 m, 3 July 2014, A. Rodríguez \& A. Rodríguez 299 (IBUG); carretera federal a Acapulco, aprox. a $10 \mathrm{~km}$ de Chilpanchingo rumbo a Acapulco., $1,276 \mathrm{~m}, 28$ October 2005, C. Castillejos-Cruz et al. 1759 (MEXU); carretera federal a Acapulco, aprox. a $10 \mathrm{~km}$ de Chilpanchingo rumbo a Acapulco, 1,038 m, 28 October 2005, C. Castillejos-Cruz et al. 1763 (MEXU). Coyuca de Benítez municipality: Pungarabato, Ilano, 22 August 1934, G.B. Hinton 6479 (GH, US); Tanghuato, 18 September 1934, G.B. Hinton 6611 (US). Eduardo Neri municipality: Amatitlán, 3.4 km al E, camino a Carrizalillo, $1680 \mathrm{~m}, 30$ September 1994, M.A. Monroy de la Rosa 594 (MEXU). Iguala de la Independencia municipality: carretera Iguala-Cd. Altamirano, 1,551 m, 25 September 2005, C. Castillejos-Cruz 1756 (MEXU); this at km $36 \mathrm{~W}$ of Iguala [km 1] on road to Teloloapan [km 63], $2 \mathrm{~km} \mathrm{~W}$ of Xalostoc, [by air ca. $20 \mathrm{~km} \mathrm{~W}$ of Iguala], 1,000 m, 30 September 1982, H.H. Iltis et al. 28644 (WIS). Mártir de Cuilapan municipality: La Esperanza, reserva campesina, 1,680 m, 6 November 1997, N. Diego et al. 7513 (FCME).

M. umbrophila. Chilapa de Álvarez municipality: $18 \mathrm{~km}$ al E de Chilapa, carr. a Tlapa, 1,950 m, 6 August 2004, A. GarcíaMendoza 7696 (MEXU); cerro a $18 \mathrm{~km}$ al E de Chilapa, carr. a Tlapa, 1,950 m, 28 November 2002, A. García-Mendoza \& A. Castañeda 7471 (MEXU); cerro a $18 \mathrm{~km}$ al E de Chilapa, carr. Tlapa-Chilapa, 1,860 m, 13 August 1999, A. GarcíaMendoza et al. 6889 (MEXU). 